\title{
Identification of Hazards and Risk Assessment for a 40kVA Diesel Powered Lighting Set.
}

\section{1'Olabiyi Banji Ajadi, ${ }^{2}$ Adegbola Amos Adekunle and ${ }^{3}$ Kolawole Oladele Peter}

\author{
${ }^{1}$ The Polytechnic Ibadan, Mechanical Engineering Dept. \\ ${ }^{2} \mathrm{Head}$ of Department, The Polytechnic Ibadan, Mechanical Engineering Dept. \\ ${ }^{3} \mathrm{FMS}$, IITA Ibadan \\ Emails: banjilabiyi@yahoo.com, kunleade2002@yahoo.com \\ Corresponding Author's Email: p.kolawole@cgiar.org
}

\begin{abstract}
The process of installing, operating and maintaining power sets carries with them occupational hazards, the hazards and risks associated with installation, operation and maintenance of diesel powered generator using a 40kVA generator was identified. The findings reveal that five major jobs or tasks were associated with the events of installation, operation and maintenance of any typical industrial standby generator. Hazards of varying degrees were identified with every section and jobbing of the whole activities. The associated risk was classification, about 60 percent high risk to 40 percent medium risk. The most hazardous tasks include, engine operation, electrical wiring and connection to the generator. The receipt and installation of the generator with preparation of foundation and engine maintenance were identified.
\end{abstract}

KEYWORDS: Diesel Power, Operation, Maintenance, Risk, Assessment

1. Introduction

Constant power supply is a measure of developed economy and any nation with epileptic power supply are prolonging their development. Developing countries are facing extreme electricity shortages (Julia, 2008). Lighting sets installation has been the alternative sources of power in conjunction with other alternative power. Risks are involved during the installation of these machines.

The process of installing, operating and maintaining power sets carries with them occupational hazards leading to injury at work place which could lead to loss of man-hours. Risk assessments are used when identifying potential hazards. The objective of the paper is to identify hazards and risks associated with installation, operation and maintenance of diesel powered generator using a 40kVA generator as case study.

The diesel engine is a type of internal combustion engine, more specifically; it is a compression ignition engine. The fuel in a diesel engine is ignited by suddenly exposing it to high temperature created by pressure of a compressed gas containing oxygen (usually atmospheric air), rather than a separate source of ignition energy (such as a spark plug). This process is known as the diesel cycle named after Rudolf Diesel, who invented it in 1892. While traditional diesel engine generators may not fit into our definition of 'alternative energy' sources, they are still a valuable addition to a remote power or grid back-up system. There are two classes of diesel engines: two-stroke and four-stroke. Most diesel engines generally use the four-stroke cycle, with some larger engines operating on the twostroke cycle. Normally, banks of cylinders are used in multiples of two, though any number of cylinders can be used as long as the load on the crankshaft is counterbalanced to present excessive vibration.

Generating sets produce either single or three phase power. Most homeowners require single phase whereas industrial or commercial applications usually require three phase power. Diesel engine generators are recommended due to their longevity and lower operating costs. Modern diesel engines are quiet and generally require much less maintenance than comparably sized gas (natural gas or propane) units. Diesel generators are designed to meet the needs of small and medium-sized businesses apart from heavy usage in industries. A generator is a revolutionary product that brings clean and affordable standby power within the reach of millions of enterprises, homes and small businesses. Reducing the cost of backup power and making generators easy to install is becoming the norm these days. Businesses lose money when they shut down during a blackout. Most modern generators are engineered to meet emergency power needs. These units continuously monitor the electrical current and automatically start up if power is interrupted and shut off when utility service is returned. In industries, during critical processes, generators can supply emergency power to all vital and selected loads as desired. This quality 
leads to widespread use of diesel-powered generators across recreational, residential, commercial, communication, and industrial applications. Today, most state-of-the-art-hospitals, five star hotels, business process outsourcing centers, manufacturing plants, telecommunications organizations, commercial buildings, data centers, emergency facilities, large industries, and mining companies require uninterrupted power and have backup diesel engine generators.

\subsection{Benefits of Diesel Generator}

\section{(a) Use of Diesel Generators as Micro Power Grids in Remote Areas}

In countries where grid infrastructures are very minimal for expansive transmission and distribution to rural areas and less cities, powering up such locations faces budgetary constraints. In this situation, the installations of diesel generators are an ideal solution to meet domestic needs and also high-energy requirements in rural areas. Diesel generators are easy to install and can either be used as standalone systems or as part of hybrid systems in conjunction with other sources like solar power. The main advantage of such a system is the sourcing of power by the lowest cost option depending on the operating environment and time of day.

\section{(b) Agriculture}

Diesel generators have established themselves as versatile and durable sources of power generation in developing countries for use in lighting, irrigation pumping, cottage industries, and rural processing facilities, just to name a few.

\section{(c) Barge-Mounted Diesel Generators (BMDs)}

BMDs are simple diesel engines and generators that are mounted on offshore barges. These units are available in a range of capacities from $5 \mathrm{MW}$ to $50 \mathrm{MW}$ and several units can be coupled together on a single barge to provide more than 100MW of power. These units can be linked to the power grid through a substation based on the shore. Unlike land-based power generation plants, BMDs makes them attractive alternative to land-based fixed power generation plants in mining and offshore drilling projects.

\section{(d) Information Technology (IT) and Data Centers}

Developing nations are increasingly becoming preferred outsourcing locations for IT projects and for setting up data centers. As it is in the developed world, diesel generators serve as one of the most efficient backup power systems in the event of power failures to prevent loss of data and to enable business continuity.

\section{(e) Infrastructure Development}

Growing economies are invariably accompanied by development in infrastructure. Diesel generators ensure roundthe-clock power supply not only in remote locations but also in the event of grid failure.

\section{(f) Bridging the Gap between Power Demand and Supply}

Even as power-generating utilities in developing nations are trying to keep pace with the rapid surge in re requirements, demand for power always seems to outpace supply, leading to peak power deficits. This can lead to scheduled and unscheduled load shedding or brownouts. The use of diesel generators as backup power units in residential and commercial building is also an attractive and widely prevalent alternative.

\subsection{Concepts of Hazards}

A hazard is an existing (or potential) hazards or unsafe condition or work practice that, by itself or in combination with other conditions, could cause injury, illness, or death to workers, as well as cause property damage. Occupational hazard may be classified into two broad categories: (i) health hazards and (ii) safety hazards. Generally, health hazards cause occupational illnesses, such as noise induced hearing loss (NHL), skin infections or impairment to any of the human body organ. Safety hazards cause physical harm, such as cuts, broken bones or fall from a height and so on. Hazards may exist from: 
(i) Processes or procedures-any series of actions or operations (manufacturing, equipment, product flow, etc., and handling) that convert raw material into a product.

(ii) Unsafe equipment, machinery, or tools-for example damaged tools, unguarded blades or unguarded moving parts, etc

(iii) Unsafe work practices - allowing untrained workers to perform hazardous tasks, taking unsafe shortcuts, being distracted, working long shifts etc.

(iv) It takes both a hazardous condition of some kind and exposure to that condition to cause an injury/illness. Therefore, the hazardous condition and/ or the exposure can be eliminated or reduced and an accident can be prevented.

\subsubsection{Control of Occupational Hazards}

The most effective methods of occupational hazards control involve either elimination or reduction of hazard and finally putting barrier between worker and hazard if require, though this is lease method. The hierarchy of hazards control includes: (i) Engineering control (ii) work practice control (iii) administrative control and (iv) personal protective equipment (PPE).

The Workplace Health and Safety Acts of 1995 imposes obligations on people at workplaces to ensure workplace health and safety. Workplace health and safety is ensured when persons are free from death, injury or harm created by workplaces, relevant workplace areas, work activities or plant/substances for use at workplace. Ensuring workplace health and safety involved identifying and managing exposure to the risks. Risk assessment provides a process that help to meet desired goal. The most effective methods of occupational hazards control involve elimination or reduction of the risks using primary control, work practice control, administrative control and personal protective equipment.

Engineering control is the first line of defense against injury, work practice control reduces explosive to hazards by changing or redesigning safe work place. The administrative control limits employees exposure thought scheduling breaks and personal protective equipment is a supplementary method by placing barriers between the workers and the hazard; the PPE devices include safety glasses, hand gloves, welding shields/helmets ergonomic equipment etc. This paper investigated the hazards and the risks involved in the installation operation and maintenance of 40kva Wilson Model P40P3 diesel generator.

\section{METHODOLOGY}

Job hazard analysis (JHA) assessment for PPE was used for this investigation. This comprises of JHA form and chart. These tools were used to break the job down into tasks for hazard/identification. Rating of probability and severity of risk was used to determine risk factors; risk priory coding was used to determine what action to be taken. Motion observational and record was used to monitor every steps involved in installation, operation and maintenance of the generator within the study area. Interview was conducted with the operating technician on the job.

Table 1: JHA form and matrix chart format

\begin{tabular}{|l|l|l|l|l|l|l|l|l|}
\hline $\begin{array}{l}\text { Job/task } \\
\text { Step }\end{array}$ & $\begin{array}{l}\text { Hazard } \\
\text { Type }\end{array}$ & $\begin{array}{l}\text { Hazard } \\
\text { Source }\end{array}$ & $\begin{array}{l}\text { Body } \\
\text { Parts at } \\
\text { Risk }\end{array}$ & probability & Severity(s) & $\begin{array}{l}\text { Risk } \\
\text { Factor (P } \\
\text { xS) }\end{array}$ & $\begin{array}{l}\text { Risk } \\
\text { Code }\end{array}$ & $\begin{array}{l}\text { Control } \\
\text { method }\end{array}$ \\
\hline & & & & & & & & \\
\hline
\end{tabular}

Analysis of the JHA form matrix chart is as follow:

(a) Probability: This is the chance that a hazard will cause harm. It is rated thus:

\begin{tabular}{|l|c|l|}
\hline Probability & Rating & Comments \\
\hline Frequent & 5 & Workers are frequently at risk \\
\hline Probable & 4 & The hazard is likely to cause harm \\
\hline Occasional & 3 & Workers are occasionally at risk \\
\hline Possible/remote & 2 & The hazard could cause harm, but is unlikely to do so. \\
\hline improbable & 1 & The hazard is unlikely to over cause harm. \\
\hline
\end{tabular}


(b) Severity: This is the seriousness of the harm that could result from contact with a hazard. It is rated thus:

\begin{tabular}{|l|c|l|}
\hline Severity & Rating & Comments \\
\hline Catastrophic & 5 & Death and/ or severe destruction \\
\hline Critical & 4 & $\begin{array}{l}\text { Serious illness, injury, disability and significant property } \\
\text { damage }\end{array}$ \\
\hline Serious & 3 & Lost time injury and property damage \\
\hline Marginal & 2 & Minor injury and property damage \\
\hline Negligible & 1 & No injury and/or property damages \\
\hline
\end{tabular}

(c) Risk Coding: This is based on the outcome of the risk factor obtained from the multiple of probability and severity.

\begin{tabular}{|l|l|c|}
\hline $11-25$ & High & H \\
\hline Risk Factor & Risk Level & Risk Code \\
\hline $5-10$ & Medium & M \\
\hline $1-4$ & Low & L \\
\hline
\end{tabular}

The study and method were solely focused on the hazards identification and consequent risk assessment there from. This was complemented by interview with the operating technicians on the job. The study was also supported with information from Manufacturer Association, trade unions and legislations from relevant government agencies.

\section{Results}

Job Hazard Analysis result and Matrix Chart for Risk Assessment in Installation, Operation and Maintenance of P40P3 FG. Wilson Standby Generator

Table 2: Job/Task: Foundation Preparation

Location: Generator House

\begin{tabular}{|c|c|c|c|c|c|c|c|c|}
\hline $\begin{array}{l}\text { Job/task } \\
\text { Step }\end{array}$ & $\begin{array}{l}\text { Hazard } \\
\text { Type }\end{array}$ & $\begin{array}{l}\text { Hazard } \\
\text { Source }\end{array}$ & $\begin{array}{l}\text { Body Parts } \\
\text { at Risk }\end{array}$ & Probability & severity & $\begin{array}{l}\text { Risk } \\
\text { Factor }\end{array}$ & $\begin{array}{l}\text { Risk } \\
\text { Code }\end{array}$ & control \\
\hline \multirow[t]{5}{*}{$\begin{array}{l}\text { Measure- } \\
\text { ment, } \\
\text { Pegging } \\
\text { \& } \\
\text { Digging }\end{array}$} & Sprain & $\begin{array}{l}\text { Digger, Shovel } \\
\text { or Spade }\end{array}$ & $\begin{array}{l}\text { Hands, back } \\
\text { fingers }\end{array}$ & 5 & 3 & 15 & $\mathrm{M}$ & $\begin{array}{l}\text { Follow } \\
\text { hierarchy of } \\
\text { control as } \\
\text { explained in } \\
\text { section } 2.6 \text { and } \\
\text { section } 4.3\end{array}$ \\
\hline & Impact & Hammer & $\begin{array}{l}\text { Hands, feet, } \\
\text { body }\end{array}$ & 4 & 2 & 8 & $\mathrm{M}$ & \\
\hline & $\begin{array}{l}\text { Airborne } \\
\text { dust }\end{array}$ & Sand particles & $\begin{array}{l}\text { Eye, } \\
\text { respiratory }\end{array}$ & 4 & 3 & 12 & $\mathrm{M}$ & \\
\hline & Penetration & Steel nails & Hands & 3 & 2 & 6 & $\mathrm{M}$ & \\
\hline & $\begin{array}{l}\text { Awkward } \\
\text { posture, } \\
\text { long } \\
\text { standing }\end{array}$ & Work postures & $\begin{array}{l}\text { Legs, back, } \\
\text { neck }\end{array}$ & 4 & 3 & 12 & $\mathrm{H}$ & \\
\hline \multirow[t]{2}{*}{$\begin{array}{l}\text { Reinforce } \\
\text { ment }\end{array}$} & Cuts & $\begin{array}{l}\text { Hack-saw, } \\
\text { metal rod \& } \\
\text { pair of plier }\end{array}$ & $\begin{array}{l}\text { Hands, feet, } \\
\text { body }\end{array}$ & 4 & 3 & 12 & $\mathrm{M}$ & \\
\hline & Penetration & $\begin{array}{l}\text { Binding wire, } \\
\text { me }\end{array}$ & Body & 3 & 2 & 6 & $\mathrm{M}$ & \\
\hline $\begin{array}{l}\text { Concentr } \\
\text { ate } \\
\text { casting }\end{array}$ & Sprain & $\begin{array}{l}\text { Bag of } \\
\text { cement, } \\
\text { concentrate } \\
\text { aggregates }\end{array}$ & $\begin{array}{l}\text { Hands, } \\
\text { back, fingers }\end{array}$ & 3 & 2 & 6 & $\mathrm{M}$ & \\
\hline
\end{tabular}


Table 2: Continues

\begin{tabular}{|l|l|l|l|l|l|l|l|l|}
\hline & $\begin{array}{l}\text { Falls and } \\
\text { slips }\end{array}$ & Wetted floor & Body & 4 & 3 & 12 & $\mathrm{M}$ & \\
\cline { 2 - 8 } & $\begin{array}{l}\text { Shovel or } \\
\text { Spade }\end{array}$ & Hands & 4 & 2 & 8 & $\mathrm{M}$ & \\
\cline { 2 - 7 } \\
$\begin{array}{l}\text { Chemical } \\
\text { and } \\
\text { airborne } \\
\text { dust }\end{array}$ & $\begin{array}{l}\text { Cement } \\
\text { particles }\end{array}$ & $\begin{array}{l}\text { Skin, eyes, } \\
\text { respiratory } \\
\text { track, } \\
\text { hands }\end{array}$ & 5 & 4 & 20 & $\mathrm{H}$ & \\
\hline
\end{tabular}

Table 3: Job/Task: Receipt and Installation of the Generator Location: Generator House

\begin{tabular}{|c|c|c|c|c|c|c|c|c|}
\hline $\begin{array}{l}\text { Job/task } \\
\text { Step }\end{array}$ & $\begin{array}{l}\text { Hazard } \\
\text { Type }\end{array}$ & $\begin{array}{l}\text { Hazard } \\
\text { Source }\end{array}$ & $\begin{array}{l}\text { Body Parts } \\
\text { at Risk }\end{array}$ & $\begin{array}{l}\text { Probabilit } \\
\text { y }\end{array}$ & $\begin{array}{l}\text { Severit } \\
y\end{array}$ & $\begin{array}{l}\text { Risk } \\
\text { Fact } \\
\text { or }\end{array}$ & $\begin{array}{l}\text { Risk } \\
\text { Code }\end{array}$ & control \\
\hline \multirow[t]{4}{*}{$\begin{array}{l}\text { Off-loading } \\
\text { the Engine }\end{array}$} & Crush & Generator & $\begin{array}{l}\text { Fingers, } \\
\text { hands, head } \\
\text { and body }\end{array}$ & 5 & 4 & 20 & $\mathrm{H}$ & $\begin{array}{l}\text { Follow } \\
\text { hierarchy of } \\
\text { control as } \\
\text { explained in } \\
\text { section } 2.6 \\
\text { and section } \\
4.3\end{array}$ \\
\hline & Impact & $\begin{array}{l}\text { Falling } \\
\text { items, } \\
\text { generator }\end{array}$ & $\begin{array}{l}\text { Feet, cured- } \\
\text { cast }\end{array}$ & 4 & 4 & 16 & $\mathrm{H}$ & \\
\hline & Cuts & $\begin{array}{l}\text { Sharp } \\
\text { edges of } \\
\text { the } \\
\text { generator } \\
\text { and hand } \\
\text { tools }\end{array}$ & Body, hands & 4 & 4 & 16 & $\mathrm{H}$ & \\
\hline & Sprain & Heavy lift & Back & 4 & 4 & 16 & $\mathrm{H}$ & \\
\hline $\begin{array}{l}\text { Installation } \\
\text { of the } \\
\text { generator }\end{array}$ & \multicolumn{8}{|c|}{ Same as off loading the generator } \\
\hline
\end{tabular}

Table 4: Job/Task: Electrical Wiring \& Connection to Generator Location: Generator House

\begin{tabular}{|c|c|c|c|c|c|c|c|c|}
\hline $\begin{array}{l}\text { Job/task } \\
\text { Step }\end{array}$ & $\begin{array}{l}\text { Hazard } \\
\text { Type }\end{array}$ & $\begin{array}{l}\text { Hazard } \\
\text { Source }\end{array}$ & $\begin{array}{l}\text { Body Parts } \\
\text { at Risk }\end{array}$ & $\begin{array}{l}\text { Probabilit } \\
\text { y }\end{array}$ & Severity & $\begin{array}{l}\text { Risk } \\
\text { Fact } \\
\text { or }\end{array}$ & $\begin{array}{l}\text { Risk } \\
\text { Code }\end{array}$ & control \\
\hline \multirow[t]{3}{*}{$\begin{array}{l}\text { Battery and } \\
\text { battery } \\
\text { connection }\end{array}$} & $\begin{array}{l}\text { Spark, } \\
\text { explosion, } \\
\text { combustibl } \\
\text { e gases. }\end{array}$ & Battery & $\begin{array}{lr}\text { Skin, } & \text { eyes, } \\
\text { hands } & \& \\
\text { body } & \end{array}$ & 5 & 4 & 20 & $\mathrm{H}$ & \\
\hline & Splash & $\begin{array}{l}\text { Battery } \\
\text { electrolyte }\end{array}$ & $\begin{array}{l}\text { Skin, eyes, } \\
\text { hands } \\
\text { body }\end{array}$ & 3 & 3 & 9 & $M$ & \\
\hline & $\begin{array}{l}\text { Electrical } \\
\text { Shock }\end{array}$ & $\begin{array}{l}\text { Battery, } \\
\text { cable \& } \\
\text { switch } \\
\text { panel }\end{array}$ & Body & 4 & 3 & 12 & $\mathrm{H}$ & \\
\hline
\end{tabular}


Table 5: Job/Task: Receipt and Installation of the Generator Location: Generator House

\begin{tabular}{|c|c|c|c|c|c|c|c|c|}
\hline $\begin{array}{l}\text { Job/task } \\
\text { Step }\end{array}$ & $\begin{array}{l}\text { Hazard } \\
\text { Type }\end{array}$ & $\begin{array}{l}\text { Hazard } \\
\text { Source }\end{array}$ & $\begin{array}{l}\text { Body Parts } \\
\text { at Risk }\end{array}$ & Probability & $\begin{array}{l}\text { Sever } \\
\text { ity }\end{array}$ & $\begin{array}{l}\text { Risk } \\
\text { Facto } \\
\text { r }\end{array}$ & $\begin{array}{l}\text { Risk } \\
\text { Code }\end{array}$ & control \\
\hline \multirow[t]{3}{*}{ Fueling } & Fire & Diesel & Skin \& body & 4 & 4 & 16 & $\mathrm{H}$ & \\
\hline & Hazardous & Diesel & $\begin{array}{l}\text { Respiratory } \\
\text { track }\end{array}$ & 4 & 4 & 16 & $\mathrm{H}$ & \\
\hline & Slips/Falls & $\begin{array}{l}\text { Wetted } \\
\text { floor }\end{array}$ & body & 3 & 3 & 9 & $\mathrm{M}$ & \\
\hline \multirow[t]{6}{*}{$\begin{array}{l}\text { Running } \\
\text { the engine }\end{array}$} & Burns & $\begin{array}{l}\text { Engine } \\
\text { block, } \\
\text { radiator }\end{array}$ & Hands, body & 4 & 4 & 16 & $\mathrm{H}$ & \\
\hline & Fire & $\begin{array}{l}\text { Diesel, } \\
\text { cables }\end{array}$ & Body & 4 & 4 & 16 & $\mathrm{H}$ & \\
\hline & Impact & $\begin{array}{l}\text { Generator } \\
\text { body, flying } \\
\text { particle of } \\
\text { broken } \\
\text { items }\end{array}$ & Feet & 3 & 3 & 9 & $M$ & \\
\hline & Vibration & $\begin{array}{l}\text { Electric } \\
\text { motor, fans }\end{array}$ & Body & 3 & 3 & 9 & $\mathrm{M}$ & \\
\hline & $\begin{array}{l}\text { Hazardous } \\
\text { gases }\end{array}$ & Exhaust & $\begin{array}{l}\text { Respiratory } \\
\text { track }\end{array}$ & 5 & 4 & 20 & $\mathrm{H}$ & \\
\hline & Noise & Engine & Ear & 5 & 4 & 20 & $\mathrm{H}$ & \\
\hline
\end{tabular}

Table 6: Job/Task: Engine Maintenance Location: Generator House/Store

\begin{tabular}{|c|c|c|c|c|c|c|c|c|}
\hline $\begin{array}{l}\text { Job/task } \\
\text { Step }\end{array}$ & $\begin{array}{l}\text { Hazard } \\
\text { Type }\end{array}$ & $\begin{array}{l}\text { Hazard } \\
\text { Source }\end{array}$ & $\begin{array}{l}\text { Body Parts } \\
\text { at Risk }\end{array}$ & $\begin{array}{l}\text { Probabilit } \\
\text { y }\end{array}$ & $\begin{array}{l}\text { Severit } \\
y\end{array}$ & $\begin{array}{l}\text { Risk } \\
\text { Fact } \\
\text { or }\end{array}$ & $\begin{array}{l}\text { Risk } \\
\text { Code }\end{array}$ & control \\
\hline \multirow{8}{*}{$\begin{array}{l}\text { Receipt \& } \\
\text { dispatch of } \\
\text { spare-parts } \\
\text { and tools }\end{array}$} & Cut & $\begin{array}{l}\text { Spare- } \\
\text { parts and } \\
\text { tools }\end{array}$ & Hands & 3 & 3 & 9 & $M$ & \\
\hline & $\begin{array}{l}\text { Crush/pinc } \\
\text { h }\end{array}$ & $\begin{array}{l}\text { Spare- } \\
\text { parts and } \\
\text { tools }\end{array}$ & Hands & 3 & 3 & 9 & $M$ & \\
\hline & Sprain & $\begin{array}{l}\text { Spare- } \\
\text { parts and } \\
\text { tools }\end{array}$ & back & 4 & 4 & 16 & $\mathrm{H}$ & \\
\hline & Impact & $\begin{array}{l}\text { Spare- } \\
\text { parts and } \\
\text { tools }\end{array}$ & Feet & 3 & 3 & 9 & $\mathrm{M}$ & \\
\hline & $\begin{array}{l}\text { Chemicals } \\
\text { irritation }\end{array}$ & $\begin{array}{l}\text { Charging } \\
\text { materials }\end{array}$ & $\begin{array}{l}\text { Respiratory } \\
\text { track }\end{array}$ & 3 & 3 & 9 & $\mathrm{M}$ & \\
\hline & Heat & Hot metal & Body & 3 & 3 & 9 & $\mathrm{M}$ & \\
\hline & $\begin{array}{l}\text { Electrical } \\
\text { shock }\end{array}$ & $\begin{array}{l}\text { Switch } \\
\text { panel, } \\
\text { battery, } \\
\text { cable }\end{array}$ & Body & 4 & 4 & 16 & $\mathrm{H}$ & \\
\hline & Slips, trips & Wet floor & Body & 3 & 3 & 9 & $M$ & \\
\hline
\end{tabular}




\section{Discussion}

The result in reveals that five major jobs or tasks were associated in the study samples. Hazards of varying degrees were identified with every section and jobbing of the whole activities. The associated risk classification is about 60 percent high risk to 40 percent medium risk. The most hazardous tasks in the study in order of risk levels include: (i) engine operation (ii) electrical wiring and connection to the generator (iii) receipt and installation of the generator (iv) preparation foundation $(\mathrm{v})$ engine maintenance. The high risk involved in the engine operation and electrical wiring and connection to the generator tasks were due to high probability of exposure of workers and critical severity of hazard, if happened. These are indeed, the most hazardous aspect of the job as hazards involve fire, shocks and electrocution, heat, hot, metal, hazardous gasses, impact, sprain and many more handlings. The study however, found out that there is less risk involved in the maintenance activities and preparation of foundation. The hazards of these sections are predominantly cut, pinch, crush, fall, impact, and sprain and contaminant dust.

It is important to note that major cause of injuries and fatalities are shocks and electrocution from improper use of power or accidentally energizing other electrical systems; carbon monoxide from a generator's exhaust and fires from improperly refueling the generator or inappropriately storing fuel and some others. All these have high potential for serious occupational illness.

\subsection{Major Hazards Identified in the Study and their Control}

The various major hazards identified in the study are:

[i] working In Heat [ii] hot metal [iii] airborne contaminants [iv] dangerous items [v] manual tasks [vi] Hazardous Substance [vii] Vibration (viii) Electricity and (ix) Plant and machinery.

\subsection{1}

Working in Heat

The engine, when working creates a hot working environment. The human body is able to function normally within $1^{\circ} \mathrm{C}$ to $1.5^{\circ} \mathrm{C}$ of a $37^{\circ} \mathrm{C}$ core body temperature. The body maintains this temperature by balancing heat generated within the body and heat loss with the environment. Working in hot environments causes strength to decline, and fatigue occur sooner than it would otherwise. Alertness and mental capacity may be affected also. Available controls include:

(a) Elimination control: this involves eliminating unnecessary sources of radiant heat and water vapour in the workplace (i.e leaks from steam valves)

(b) Altering the work environment

- Modifying the air temperature, relative humidity and air movement using general or local ventilation, spot coolers, fans, air conditioning.

- Using ventilation

(c) Administrative Control

* Encouraging workers to take short breaks

* Decreasing heat exposure duration e.g rotation of workers

* Screen workers for heat intolerance (e.g. those with heart and blood pressure problems or previous heat illness)

* Rescheduling hot work to cooler parts of the day and maintenance to cooler seasons.

(c) Use of PPE Devices: this includes ultra violet glasses, non - flammable and heat reflective clothing and equipment, water cooled suits/vests and other equipment and protective gloves and footwear.

\subsubsection{Airborne contaminants}

Significant concentrations of airborne contaminants may be encountered in installation, operation and maintenance of any typical industrial standby generator. Dust from wood, and silica constitutes serious occupational hazards.

(a) Use of PPE Device: such as eye and face protectors and respirators with organic filter for organic vapours. 


\subsubsection{Dangerous items}

These are materials that have ability to cause or accelerate (i) fire (ii) acute toxic effects and (iii) corrosion of skin and other materials. Control measures involve elimination, isolation, classification and the use of PPE devices.

\subsubsection{Manual Tasks}

Manual tasks are part of nearly all work done by workers. They include any activity where workers grasp, manipulate, carry, and move (lift, lower, push, pull), bold or restrain a load. Available controls are stated below:

(a) Design Control: This involves job design and redesign control. It requires the arrangement, or alteration of the work process or physical aspects of the workplace such as equipment or worker stations.

(b) Provision of mechanical aids: some devices that may reduce the manual handling are conveyor systems, cranes, hoists, forklift trucks and roller systems.

(c) Administrative Control

* Task - specific training

* Work organization

* Preventative maintenance programs

* Personal protection equipment (PPE)

\subsection{Hazardous Substances}

Carbon Monoxide Poisoning: Carbon monoxide (CO) is a colorless, odorless toxic gas. Many people have died from $\mathrm{CO}$ poisoning because their generator was not adequately ventilated.

- Never use a generator indoors.

- Never place a generator outdoors near doors, windows, or vents.

- If you or others show symptoms of CO poisoning - dizziness, headaches, nausea, tiredness - get to fresh air immediately and seek medical attention.

Health effects of prolong exposure include: headaches, fatigue, asthma, chemical burns, and damage to lungs, liver and kidneys. Controls are almost as discussed in airborne contaminants and dangerous items.

\subsubsection{Vibration}

Exposure to noise is always accompanied by exposure to vibration. Vibration could be (i) whole body vibration (1 to $80 \mathrm{H}_{\mathrm{z}}$ ) or (ii) hand-arm or segmental vibration $\left(8 \mathrm{H}_{\mathrm{z}}\right.$ to $1 \mathrm{kH}_{\mathrm{z}}$ ). Vibration is common during when generator engine is running. Health effects include blood pressure, heart problem disorders, joint and spine damage.

\subsubsection{Electrical Hazards}

All power voltage supplies should be turned off at the source while installing or servicing the generator. All electrical connections, such as wires, cables and terminals must be properly insulated and covered, and should not be touched with bare hands or while in contact with water, this is essential to prevent the occurrence of an electric shock. The frame of the generator and any external conducting parts should have proper grounding/earthling wiring. This should never be disconnected. 4 . Wiring, cable and cord sets must be of the recommended capacity.

\subsubsection{Fire and Explosion Hazards}

Smoking in the vicinity of the equipment can be fatal. Fuel or oil spills around the generator, leakages from the unit's fuel system and fuel supply lines, and presence of combustible materials around the generator will pose a risk of an explosion. A fire extinguisher should be readily available. Use of extinguisher that operate on carbon tetra-chloride is strictly prohibited since the fumes are toxic and can deteriorate the insulation on the wiring of generators.

\section{Conclusion}

The study investigated the hazards and assesses the risks involved in the installation, operation and maintenance of FG Wilson Model P40P3 industrial standby diesel generator with a rated power prime of $40 \mathrm{kVA}$. Job hazard analysis 
(JHA) Assessment for Personal Protective Equipment (PPE) was used for the investigation of risk assessment. This comprises of (i) the JHA form and (ii) the JHA matrix chart/table. This tool helps to: (i) break down the job into tasks or steps (ii) identify hazard types and sources (iii) assign ratings to probability and severity of risk in order to determine risk factor (iv) assign risk priority code and (iv) determine what action to be taken.

The findings reveal that five major jobs or tasks were associated with the events of installation, operation and maintenance of any typical industrial standby generator in the study samples. Hazards of varying degrees were identified with every section and jobbing of the whole activities. The associated risk classification is about 60 percent high risk to 40 percent medium risk. The most hazardous tasks in the study in order or risk levels include: (i) engine operation (ii) electrical wiring and connection to the generator (iii) receipt and installation of the generator (iv) preparation foundation (v) engine maintenance. The high risk involved in the high probability of exposure of workers and critical severity of hazard, if happened. These are indeed, the most hazardous aspect of the job as hazards involve fire, shocks and electrocution, heat, hot metal, hazardous gasses, impact, sprain and many more handlings. The study however, found out that there is less risk involved in the maintenance activities and preparation of foundation. The hazards of thee sections are predominantly cut, pinch, crush, fall, impact, and sprain and contaminant dust.

It is important to note that major causes of injuries and fatalities are shocks and electrocution from improper use of power or accidentally energizing other electrical systems; carbon monoxide form a generator's exhaust and fires from improperly refueling the generator or inappropriately storing fuel and some others. All thee have high potential for serious occupational illness.

These hazards can be controlled in a numbers of ways that include: eliminate, substitution, isolation, engineering, administrative, work practice control and with the use of personal protective equipment (PPE).

\subsection{Recommendation}

The findings in this work can be used for training and also serve as an important handbook for Safety Personnel, both in the private and public enterprises. The outcome of the investigation may also serve as an information source for safety regulations and legislations.

\section{References}

Julia Kennedy (2008): The Energy Crisis of Nigeria: An overview and implications for the Future, The University of Chicago.

Sambo, A.S. (2005) Renewable Energy for Rural Development: The Nigerian Perspectives ISESCO Science and Technology Vision: 12-22

The Punch (2010): How 834 companies closed down in Nigeria, Sunday October 31 ${ }^{\text {st }}$. 2010, Vol. 17, No. 19610.

Tyleo, Gerald (2002) Public and Private Electricity Provision as a Barriers to Manufacturing Competitiveness" Africa Regions Findings. World Bank, htp:/www.worldbank.org/afr/findings/English/find221.pdf 